\title{
INDICATING VERTICAL DEVIATION OF HISTORICAL BUILDINGS USING GEODETIC METHODS - CASE STUDY OF BRICK AND WOOD TOWER IN NOWE MIASTECZKO
}

\author{
Maria MRÓWCZYŃSKA ${ }^{1}$, Sławomir GIBOWSKI ${ }^{2}$ \\ University of Zielona Gora, Zielona Góra, Poland
}

\begin{abstract}
The article presents the possibilities of applying geodetic methods to determine the vertical deviation of historical buildings. In particular, the results of measurements obtained for a brick and wood Town Hall Tower located in the town of Nowe Miasteczko have been presented. Geodetic measurements of vertical deviation taken before and after carrying out repairs which were aimed at stopping or eliminating the destructive processes of degradation taking place, especially in the wooden part of the tower. During the renovation works, attention was also given to improving the technical condition of the building, which was reflected by the results of the measurements and calculations.
\end{abstract}

Keywords: vertical deviation, geodetic measurements.

\section{TECHNICAL DESCRIPTION OF ANALYZED BUILDING}

The town hall tower, which was subjected to the measurements of vertical deviation, is located in the town of Nowe Miasteczko, in a building under the administration of the Nowe Miasteczko City Council, on record parcel No. 234/2. The construction of the town hall building began in 1664 and lasted until

\footnotetext{
${ }^{1}$ Corresponding author: University of Zielona Gora, Faculty of Building, Architecture and Environmental Engineering, Z. Szafrana st 1, 65-516 Zielona Góra, Poland, e-mail: m.mrowczynska@ib.uz.zgora.pl, tel.+48683282636

2 Corresponding author: University of Zielona Gora, Faculty of Building, Architecture and Environmental Engineering, Z. Szafrana st 1, 65-516 Zielona Góra, Poland, e-mail: s.gibowski@ib.uz.zgora.pl, tel.+48683282636
} 
the end of the XIX century, whereas the actual tower, approx. $34 \mathrm{~m}$ high and exhibiting the baroque style of architecture, was added on to the west wing in XVIII [4]. Up to a height of $17.40 \mathrm{~m}$, the tower was constructed from solid ceramic brick in lime mortar, while above this height, the construction of the tower is wooden and finished off with a spire-steeple. As a result of the observations carried out, damage to the construction of the wooden part of the tower was confirmed, caused by humidity and biodegradation. Damage affected elements such as: the lower boarding of the cupola, the load-bearing post of the outside street lamp, inside load-bearing posts, the connections of noggins with the posts, as well as the degradation of the spire-steeple covering [4]. The scope of the renovation works carried out included: new boarding of the tower cupola, replacing interior and exterior load-bearing posts, strengthening the remaining load-bearing posts using angle struts, and a spire-steeple cover made of copper.

\section{LEGAL REGULATIONS REGARDING THE MEASUREMENT OF DISPLACEMENTS AND DEFORMATIONS}

In order to determine possible abnormalities in buildings and structures over the course of construction and use, and in situations where a threat is posed by, e.g. design or construction flaws, defective work or the degrading technical condition, they are subjected to measurements of displacements and deformations [1]. The means and manner of carrying out these types of measurements are regulated by the Regulation of the Minister of Land Development and Construction of 21 February 1995 on the Type and Scope of Geodetic-Cartographic Documents and Obligatory Surveyor's Activities in Construction, as well as by the norm PN- ISO 4463-3:2001 Measurement Methods for Building - Setting out and Measurement - Check-lists for the Procurement of Surveys and Measurement Services.

According to the regulation [6], in order to ensure the security of the building structure and safety of its maintenance, geodetic tasks connected with the geodetic determination of building displacements and land movements of the ground on which it is located, as well as measurements of building deformations are conducted ( $\S 14$.). Seasonal geodetic measurements of displacements and deformations are carried out if the project design calls for such measurement or upon request of an entity interested in such information (\$18.2).

The PN-ISO 4463-3:2001 standard informs that monitoring displacement and deformation can be required of existing as well as newly constructed building structures, adjacent buildings, land movements or changes in the groundwater level. The standard [7] also emphasizes the necessity to select appropriate 
methods and tools of measurement, and establish the frequency and accuracy of measurements, as well as the proper location of observation stations.

\section{METHODS OF MEASURING VERTICAL DEVIATION}

Measuring the vertical linearity of tower structures is aimed at indicating the value of deviation from the vertical or linear course of the geometrical axis of the building structure. High tower structures are exposed to the effects of many external factors, which can be divided into three groups [3]:

- mechanical effects (own weight of the structure, influence of subgrade deformations, influence of mining exploitation, dynamic influences, wind load),

- thermal effects (uneven exposure to sunlight),

- physico-chemical effects (rheology and relaxation).

In the case of historic buildings, the values of the obtained deviations of the geometrical axis from the vertical are also influenced by factors connected with the worsening technical condition of the building [5]. The influence of the listed factors makes it possible for the tower structure to undergo quick-changing elastic deformations (under the influence of von Kármán vortices), daily elastic deformations (effect of exposure to sun, the effects of wind), as well as permanent deformations.

The measure of the vertical trueness of the geometrical axis of the tower can be taken using the following geodetic methods: directional method (of bisectors), resection method, linear method and direct projection method. Irrelevant of the method chosen, similar guidelines must be followed in the measurements [2, 3]:

- measurement control network points (measurement stations) are set up so as to ensure good visibility of the entire building from each of the measurement points.

- lines of collimation cutting into the measurement points from the individual measurement stations ought to intersect each other at an angle

- of approximately $90^{\circ}$,

- the distance between the measurement station and building with a height of $h$ should be at least $1.5 h$,

- the measurement cross-sections must be identified from the measurement stations.

Due to the location of the Town Hall (center of the town - dense housing development), the method of direct projection was used to measure displacement. The method involved projecting measurement points located, e.g. on the edge of the building from observation stations onto a leveling staff using 
a theodolite or tacheometer. The leveling staff on which the reading determining the linear location of the point is read ought to be placed horizontally and perpendicularly to the direction of the instrument's station axis of building structure. The difference between the readings at following points in relation to the measurement point located lowest on the edge of a building, the so-called zero point, informs us about the deviation of the edge of the building from the vertical at the observed point.

\section{RESULTS}

In order to determine the vertical deviation of the tower constituting a part of the Town Hall located on Rynek 2 St. in Nowe Miasteczka, two periodical measurements were taken: prior to the renovation of the tower (March 2010) and upon completing the remodeling works (September 2010). Due to the brickwooden construction of the building structure, corners A and B located on the brick section of the tower and tower axes marked as $\mathrm{E}$ and $\mathrm{F}$ were selected for measurements (Fig. 1 and 2).

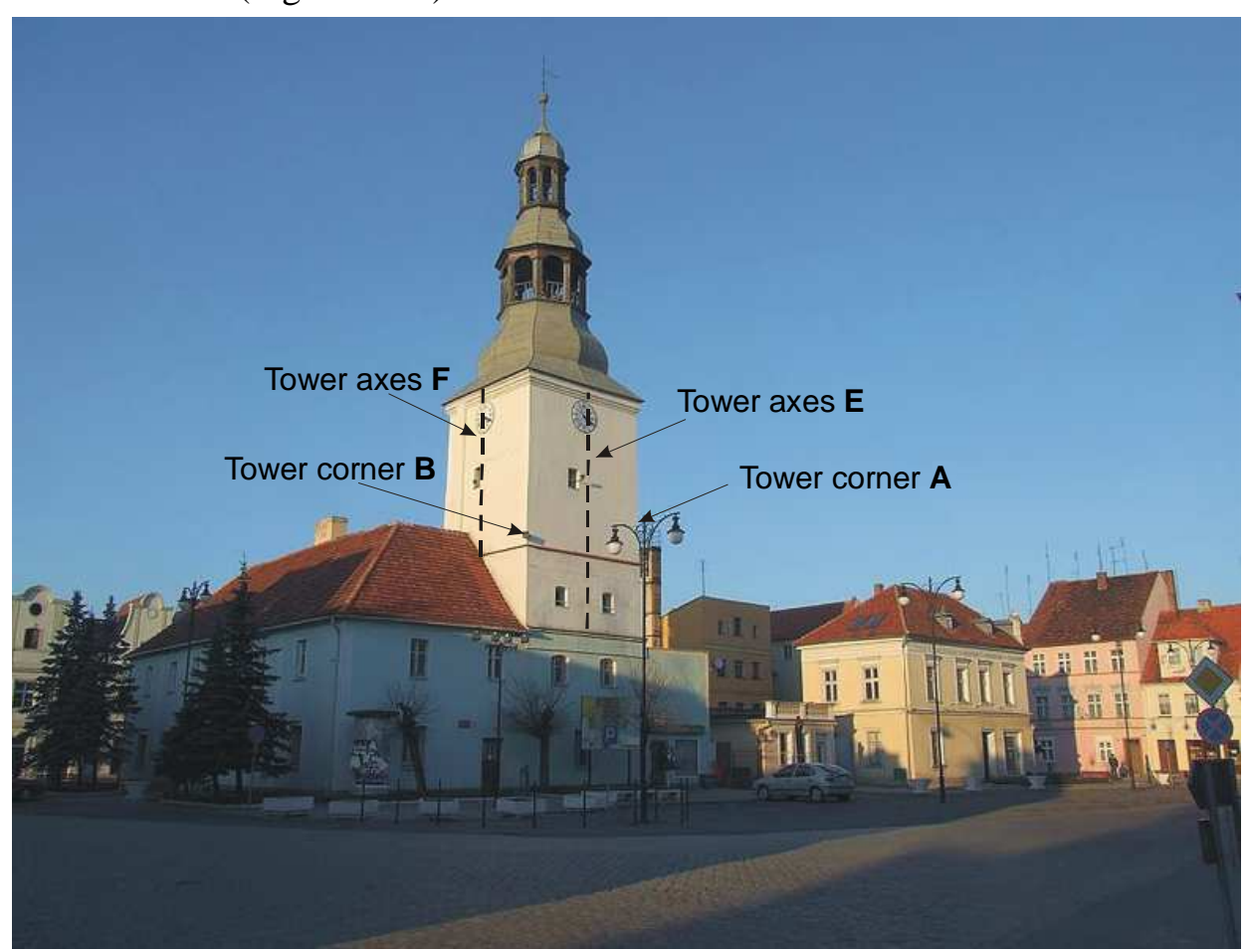

Fig. 1. Tower corners and axes subjected to measurements 


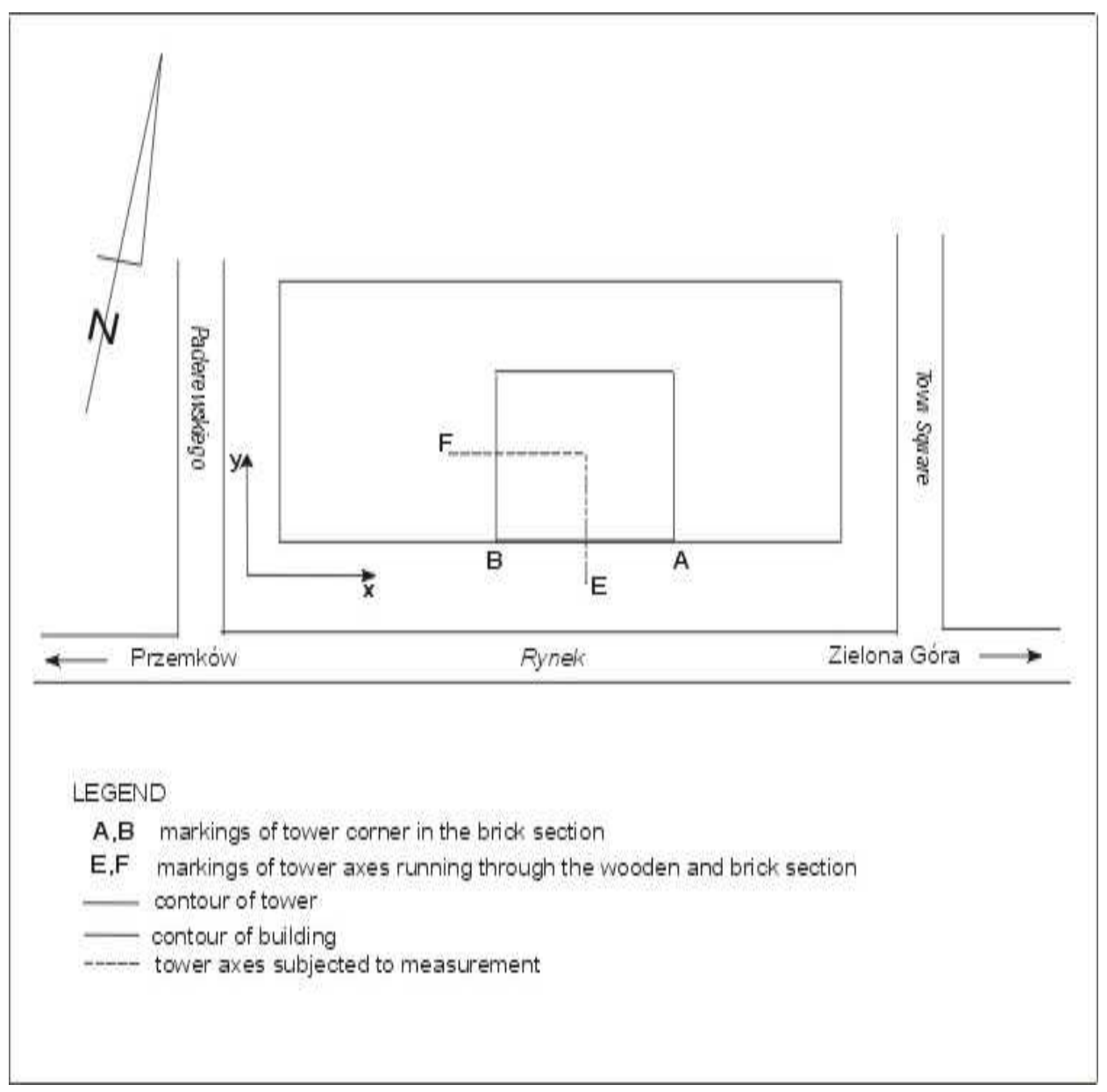

Fig. 2. Building location along with the arrangement of corners and axes

Measurement of vertical deviations by method of direct projection was carried out at 4 measurement points located at given levels of two corners (A and B ) of the brick section - attention should be paid to the fact that one of the points (marked in Fig. 3 as 1R) was a reduction due to the change in the thickness of exterior walls, and at 4 measurement points located at given levels of two axes $(\mathrm{E}$ and $\mathrm{F})$ running through the brick as well as wooden part of the tower (Fig. 4). 


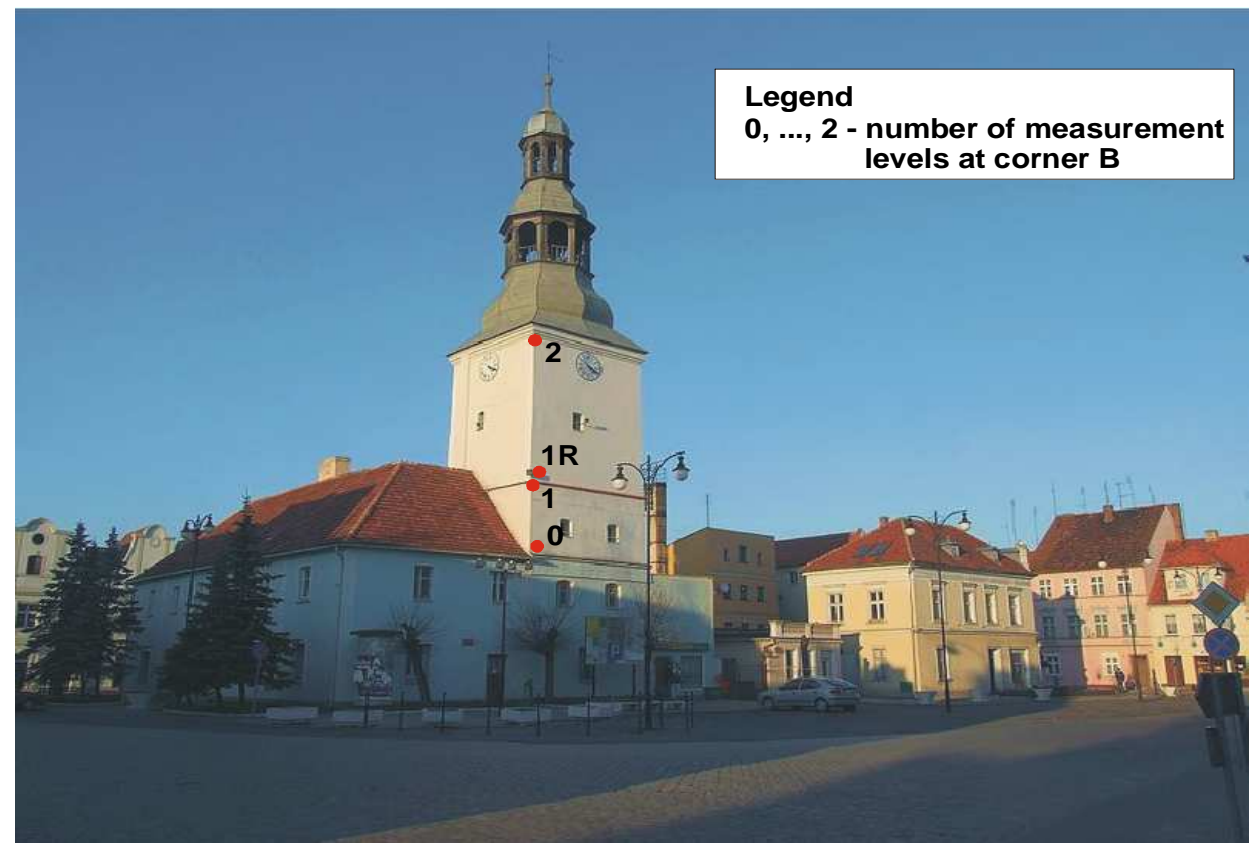

Fig. 3. Measurement levels on brick section of the tower

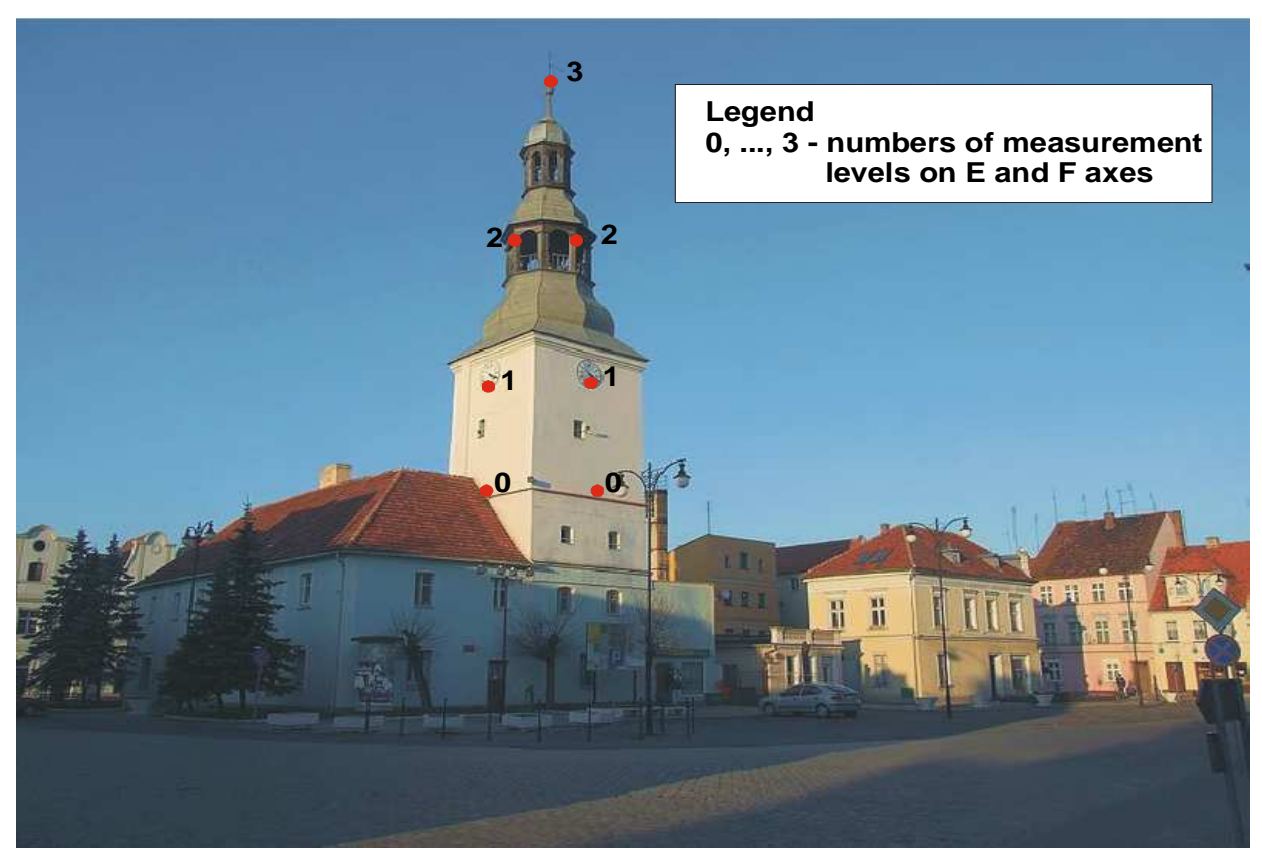

Fig. 4. Measurement levels on the axis of the wooden section of the tower 
Maximum vertical deviations obtained from carrying out two periodical measurements have been presented in Table 1. Taking into consideration the measurement of vertical deviations taken for the tower axis, it was confirmed that the observed deviations are significantly larger than the deviations of the corner edges of the tower, and reach a maximum value of $511.7 \mathrm{~mm}$ before renovation and 265.2 after renovation at the last (4th) measurement level. Level 4 was located at a height of $34.09 \mathrm{~m}$.

Table 1. Maximum vertical deviation

\begin{tabular}{|c|c|c|}
\hline \multirow{2}{*}{$\begin{array}{c}\text { Corner or } \\
\text { axis }\end{array}$} & \multicolumn{2}{|c|}{ Maximum deviation in [mm] recorded from measurement } \\
\cline { 2 - 3 } & initial (03.2010) & current $(09.2010)$ \\
\hline A & 144.1 & 134.6 \\
\hline B & 86.4 & 81.0 \\
\hline E, F & 511.7 & 265.2 \\
\hline
\end{tabular}

It ought to be pointed out that, in relation to the initial measurement carried out in March 2010, the values of deviation were reduced by $-26.4 \mathrm{~mm}$ for corner A, $-5.4 \mathrm{~mm}$ for corner $\mathrm{B}$, and $-246.5 \mathrm{~mm}$ for tower axes $\mathrm{E}$ and $\mathrm{F}$. A compilation of changes in the vertical deviation at the individual levels from the initial measurement to the current one has been presented in Table 2. Deviations of the tower axis obtained at the initial measurement (prior to renovation) and the current measurement (following renovation) have also been presented graphically in Fig. 5.

Table 2. Differences in deviation between the initial and current measurement

\begin{tabular}{|c|c|}
\hline No. of point & $\begin{array}{c}\text { Differences in deviations between the current and initial } \\
\text { measurement }[\mathrm{mm}]\end{array}$ \\
\hline \multicolumn{2}{|c|}{ Corner A } \\
\hline 0 & 0.0 \\
\hline 1 & -26.4 \\
\hline 2 & -9.5 \\
\hline 0 & Corner B \\
\hline 1 & 0,0 \\
\hline 2 & $-5,4$ \\
\hline \multicolumn{2}{|c|}{$+1,2$} \\
\hline 0 & Tower axis E and F \\
\hline 1 & \multicolumn{2}{|c|}{0.0} \\
\hline 2 & -59.4 \\
\hline 3 & -87.6 \\
\hline
\end{tabular}




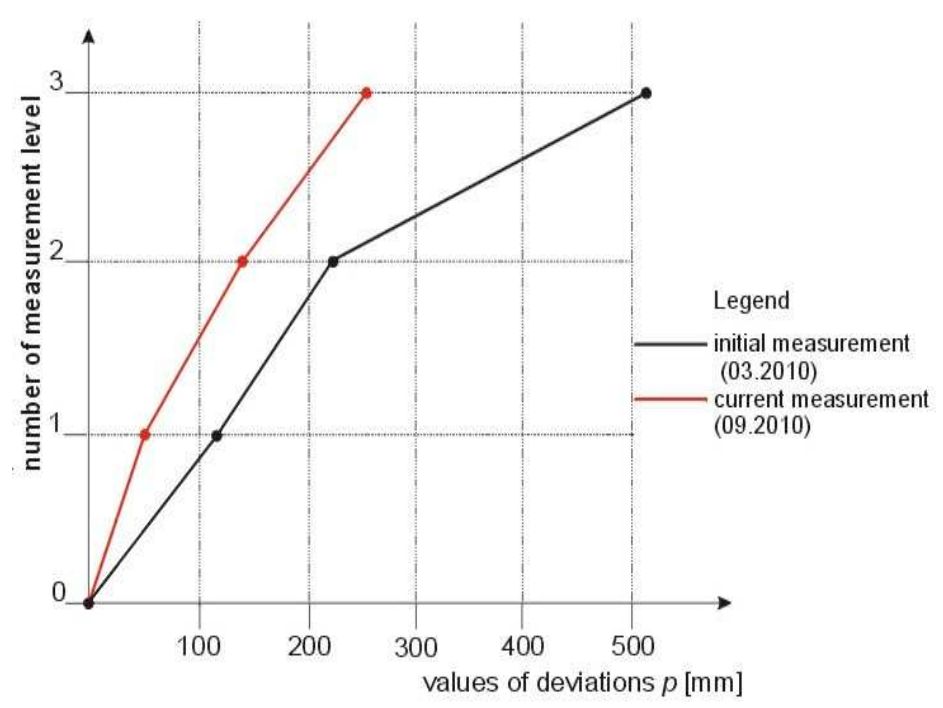

Fig. 5. Deviation of tower axis in initial and current measurement

\section{CONCLUSIONS}

Measurements of the displacements and deformations of historic buildings are carried out in order to provide information regarding changes in the condition of the building over a given time period. Controlling the changes in the location of historic building elements during the time they are in service can be a onetime or periodical event. A single measurement provides information about the current state of the building and can be compared to a theoretical model. In cases when renovation works are being carried out, geodetic measurements taken at given intervals of time make it possible to determine whether the repairs made within the scope of these works have led to the desired effect. When considering the measurement and calculation results obtained in the present study, it can be said that the renovation works carried out on the tower of the Town Hall in Nowe Miasteczko did in fact provide the anticipated effects, and the deviation of the geometrical axis of the tower from the vertical decreased by as much as $25 \mathrm{~cm}$.

\section{REFERENCES}

1. Jagielski A.: Podstawy geodezji inżynieryjnej, Kraków, Wydawnictwo GEODPIS 2012. 
2. Jasiak A., Jelonkiewicz H., Wójcik M., Wyczółek I.: Pomiary inżynierskie, Poznań, Wydawnictwo Politechniki Poznańskiej 1999.

3. Geodezja inżynieryjna, tom II, redaktor I. Laudyn, Polskie Przedsiębiorstwo Wydawnictw Kartograficznych, Warszawa 1994.

4. Laskowski J., Dankowski M.: Remont wieży ratusza w Nowym Miasteczku, Przegląd Budowlany, 3/2013, 92-94.

5. Sztubecka M.: Monitoring stabilności przestrzennej kamiennych budowli zabytkowych. III Konferencja Naukowo - Techniczna Budownictwo ogólne. Zagadnienia konstrukcyjne, materiałowe i cieplno-wilgotnościowe w budownictwie, Bydgoszcz - Ciechocinek 2003.

6. Rozporządzeniu Ministra Gospodarki Przestrzennej i Budownictwa z dnia 21 lutego 1995 r. $w$ sprawie rodzaju i zakresu opracowań geodezyjnokartograficznych oraz czynności geodezyjnych obowiqzujacych w budownictwie, Dz. U. z 1995 Nr 25, poz. 133.

7. Norma PN-ISO 4463-3:2001 Metody pomiarowe w budownictwie - Tyczenie i pomiar - Wykazy sprawdzajace dla realizacji zadań geodezyjnych i ustug pomiarowych.

\section{WYZNACZENIE WYCHYLEŃ OBIEKTÓW ZABYTKOWYCH Z WYKORZYSTANIEM METOD GEODEZYJNYCH NA PRZYKŁADZIE WIEŻY O KONSTRUKCJI MUROWANO DREWNIANEJ W NOWYM MIASTECZKU}

\section{Streszczenie}

W artykule przedstawiono możliwości zastosowania metod geodezyjnych do wyznaczenia odchyleń od pionu obiektów zabytkowych. W szczególności zaprezentowano wyniki pomiarów uzyskanych dla murowano-drewnianej wieży ratusza położonego w miejscowości Nowe Miasteczko. Pomiary geodezyjne wychyleń od pionu zostały wykonane przed i po przeprowadzonych pracach remontowych, mających na celu powstrzymanie i wyeliminowanie destrukcyjnych procesów korozyjnych rozwijających się zwłaszcza w drewnianej części wieży. Podczas prac remontowych zwrócono również uwagę na poprawę stanu technicznego obiektu, co znalazło swoje odzwierciedlenie w uzyskanych wynikach pomiarów i obliczeń

Słowa kluczowe: wychylenia od pionu, pomiary geodezyjne.

Editor received the manuscript: 12.08.2015 
